\title{
No evidence of association between Atherosclerosis, risk factors for cardiovascular disease and human T-cell lymphotropic virus type 1(HTLV-1) infection
}

\author{
Glauco Moniz de Aragão Dória', Viviana Olavarria Gallazzi ${ }^{1}$, Ney Boa-Sorte', Maria Fernanda Rios Grassi ${ }^{1,2}$, \\ Bernardo Galvão-Castro ${ }^{1,2^{*}}$
}

From 17th International Conference on Human Retroviruses: HTLV and Related Viruses

Trois Ilets, Martinique. 18-21 June 2015

HTLV-1 induces a persistent infection leading to an increased production of inflammatory cytokines. HIV, another retrovirus that causes systemic inflammation, is associated with atherosclerosis. However, few is known about HTLV-1-infection and atherosclerosis. To determine the prevalence and risk factors associated with atherosclerosis in patients infected with HTLV-1. a cross-sectional study involving 54 HTLV-1-infected patients (24 asymptomatic and 30 HAM/TSP), was carried out at the CHTLV between 2012 to 2013. Sociodemographic and cardiovascular risk factors were evaluated (age, sex, arterial hypertension, hypercholesterolemia, diabetes mellitus and smoking). Patients were submitted to Doppler echocardiography of both carotid and vertebral arteries to measure intimal-media layer. The association between intima-media thickness (IMT) and HAM/TSP diagnosis, HTLV-1 proviral load, lowdensity lipoprotrein cholesterol (LDL-c) or ultrasensitive $\mathrm{C}$-reactive protein was determined. The mean age of patients was $57.1 \pm 12.3$ years, $72.2 \%$ were women. Clinical atherosclerosis (IMT $\geq 1.5 \mathrm{~mm}$ ) was found in nine patients (16.7\%) and subclinical atherosclerosis (IMT $>1$ and $<1.5)$ in 10 patients $(18.5 \%)$. Atherosclerosis was more frequent in women $(41 \%)$ compared with man $(20 \%)$. Median age was significantly higher in patients with atherosclerosis $(p=0,2)$. The mean of LDL-c level was $140.11 \pm 43.25 \mathrm{mg} / \mathrm{dl}$ (ranging from 49 to $287 \mathrm{mg} / \mathrm{dl}$ ). No significant differences were observed between the mean LDL-c level in individuals with subclinical $(126.10 \pm 38.95 \mathrm{mg} / \mathrm{dl})$ and with atherosclerosis diagnosis

\footnotetext{
* Correspondence: bgalvao@bahiana.edu.br

${ }^{1}$ Centro Integrativo e Interdisciplinar de HTLV (CHTLV), Escola Bahiana de

Medicina e Saúde Pública, Salvador, Bahia, Brasil

Full list of author information is available at the end of the article
}

$(144 . \pm 43.87 \mathrm{mg} / \mathrm{dl})$, compared with individuals with normal IMT $(143.21 \pm 44.65 \mathrm{mg} / \mathrm{dl}),(\mathrm{p}=0.4175)$. There was no correlation between HTLV-1 proviral load and IMT. No association was found between HTLV-1 infection and clinical or subclinical atherosclerosis as well as with the risk factors for cardiovascular diseases. A positive association between atherosclerosis and age was observed.

\section{Authors' details}

${ }^{1}$ Centro Integrativo e Interdisciplinar de HTLV (CHTLV), Escola Bahiana de Medicina e Saúde Pública, Salvador, Bahia, Brasil. ²Laboratório Avançado de Saúde Pública, Centro de Pesquisas Gonçalo Moniz, Fundação Oswaldo Cruz/Bahia, Brazil.

Published: 28 August 2015

doi:10.1186/1742-4690-12-S1-P30

Cite this article as: de Aragão Dória et al: No evidence of association between Atherosclerosis, risk factors for cardiovascular disease and human T-cell lymphotropic virus type 1(HTLV-1) infection. Retrovirology 2015 12(Suppl 1):P30.

Submit your next manuscript to BioMed Central and take full advantage of:

- Convenient online submission

- Thorough peer review

- No space constraints or color figure charges

- Immediate publication on acceptance

- Inclusion in PubMed, CAS, Scopus and Google Scholar

- Research which is freely available for redistribution Submit your manuscript at
www.biomedcentral.com/submit C Biomed Central 